著しく大きいのであり，セロファンが透さなかつた $2960 \AA ̊$ の輻射 線をす透す。斯る理由を以て空がラス及セロフっント比べでト ロフィルムを演光障とした時隹銅價の大きいことは當然である。

头にアセテート・フィルムを透り得る輻射線はニトロフィルムと 同じであるが但し透光率は稍大である。從でトロフィルムを用 ひた場合よりひ銅價の少しく大なるに不思議はない。

最後にアセテートフィルムと石英ガラスとを濾光障とした場合 の銅價を比較すると $2.257-1.848=0.409$ であつて石英ガラスを 使用する時の方が著しく大きい。之は石英がラスはアセテート フィルムの透し得ない 2640 及 $2520 \AA$ 等の短波長輻射楾を透すば かりでなく輻射線の 總てを通じて透光率が大であるからであら So;

終結

本窑驗より得られる結諭は水銀石英燈の 1 時間 92 93W の供 給エホルギーによる照射では $3640 \AA$ よりも長波長輻射線の作用 では䊼維素の光化學攀化は殆ど起らない。

水銀石英䌡の輻射缐の中ア七テートフィルムを透り得る紫外線
例へば波長 3640 及 $3120 \AA$ の光は極めて强く石英ガラスのみを 透り得る其以下の波長の輻射線は甚げ弱い。而して波長 $3610 \AA$ の輻射線がアセテート・・1ルム及石英ガラスを透る率は略了同じ

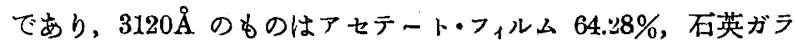
ス $83.28 \%$ である。因て後者の方が此輻射線を約 $20 \%$ がた多く 透す。然るに銅價の增加に現はれた光化學䇾化は石英ガラスを以 て濾光した時の方が 2 倍以上に及がのであつて決して $20 \%$ ば かりの增加ではない。石英ガラスのやらに殆ど總ての輻射線を透 す時の其等の綜合的の影響は個々の單獨の輻射線の影響の和より も大であることも一部分の理由に相違ないが，結局はア七テー トフィルムを透らないで石英がラスを透る波長 2640 及 2520 亿 云ふやうな短波長輻射線の哃す影響の結果として銅價の塤加に大 きな差が生じたものと思はなければならない。而す斯る短波長紫 外線は弱いのであるから逆に其等の策寸光化學作用は强いるのと

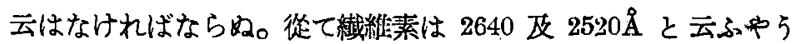

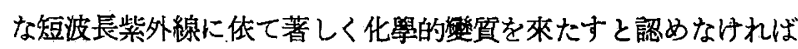
ならぬ。

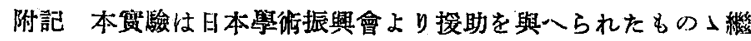
縝研究であるてとを附記して謝意を表する。

（早稻田大學理工學部㮣用化學科研究空）（昭利 12 年 11 月 12 日受理）

\title{
（2）光に依る織維素の光化學變化の研究（第１1 報)
}

\section{織維素の光化學變化に與へる水の影響}

\section{小 栗 捨 藏}

藮に著者（本誌，昭和 $9 ， 37 ， 1279$ ) は織維素試料を水に濡ら して水銀石英燈の光に 1 時間觸れさせても試料の銅價は水に濡ら さずして同樣に光を照射せし場合と變らぬこと言ひ換へれば水の 影響は認められぬことを報告したが，其賽驗は定性的の域を脫し なかつた雹今少し詳細なる實驗を行ふべき必耍のあることを感 したので改めて實驗を施行した。本文は其䔈驗結果を緾めたりの である。

\section{(1) 賽 駼 其 1}

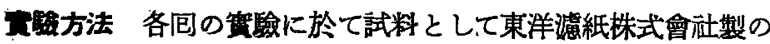
定量用濾紙 2 枚を取り，之等を充分よく水に渍けて其中の 1 枚 を取り夫々酸素中，空素中及空氣中にて1時間水銀石英燈 (アク ×太陽嬁 $100 \mathrm{~V} 2 \mathrm{~A}$ ) の光て照射したる後, 空氣中に 1 日間放置
して秤量して試料の重量を知ると共に他の 1 林は同時間同じ場所 に放置して光に照射せる試料と同じ水分を特たしめるやらにして 秤量し水分を定量した。而して光にて照射せる試料に就てはシュ ワルベ・ブレーディー法に依て銅價を測定した。

なほ光にて 照射する時の 裝置及條件等は第 8 報 (本誌, 昭和 12，40，651）に報告した處と全く同じである。試料す亦第 8 報 の賏驗で使用したものと同じである。

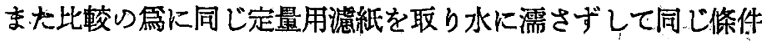
の下で試料の銅價を測定した。

贯䮩結果 先づ順序として水に濡ざずして銅價を測定せる結果 を第: 1 表に示す。

次に水にて濡らして水銀石英登の光を照射して銅價を測定せる 絡果を第 2 表に揭げる。

第 1 表 水に濡さずして光を照射した試料の銅價

酸素中にて光を照射せる場合 坒氣中にて光を照射せる場合

\begin{tabular}{|c|c|c|}
\hline 䇦跧番號 & 乾嬠試料 (g) & 銅 \\
\hline 68 & 0.6408 & 1.18 \\
\hline 71 & 0.6325 & 1.511 \\
\hline 74 & 0.6370 & 1.519 \\
\hline 77 & 0.5927 & 1.549 \\
\hline \multirow[t]{2}{*}{80} & 0.6066 & 1.555 \\
\hline & 平均 & 1.54 \\
\hline
\end{tabular}

\begin{tabular}{|c|c|c|}
\hline 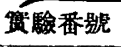 & 乾焒試料 (g) & 銅 但 \\
\hline 69 & $0.6 ะ 26$ & 1.504 \\
\hline 72 & 0.6017 & 1.448 \\
\hline 75 & $0.5 \div 87$ & 1.493 \\
\hline 78 & 0.6423 & 1.503 \\
\hline \multirow[t]{2}{*}{81} & 0.6002 & 1.479 \\
\hline & 平均 & 1.485 \\
\hline
\end{tabular}

\begin{tabular}{|c|c|c|}
\hline 䛼驗番號 & 乾喍試料 (g) & 銅 鼬 \\
\hline 66 & 0.6405 & 1.341 \\
\hline 67 & 0.6401 & 1.286 \\
\hline 70 & 0.6134 & 1.361 \\
\hline 73 & 0.6208 & 1.383 \\
\hline 76 & 0.6200 & 1.405 \\
\hline 79 & 0.5879 & 1.358 \\
\hline 82 & 0.5836 & 1.369 \\
\hline
\end{tabular}


第 2 表 水で濡らして光を照射せる試料の銅價

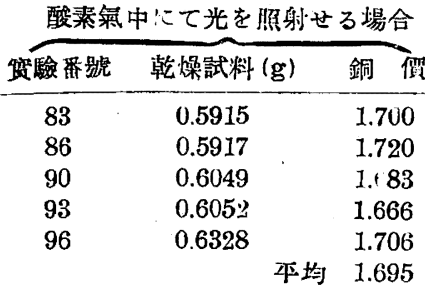
坒氯中:て光を暨射せる場合

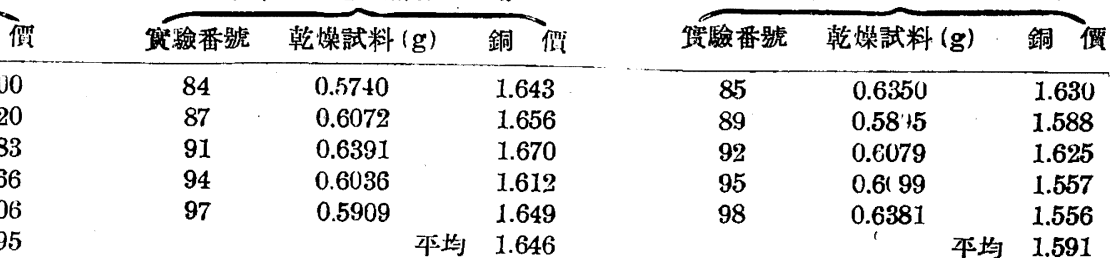

窒素氣中心て光を照射せる場合

第 3 㳖 水で濡らした時と濡らさ娃の銅價增加の比較佔

水で濡らした時の銅侕の

$1.591-0.888=0.703$
水で濡らさ娃の銅翼の暂加
$1.544-0.888=0.656$
$1.485-0.888=0.597$
$1.358-0.888=0.470$

因に第 1 表及第 2 裴の窅醶に使用せる酸素はボンブ酸素であ り, 又使用空素は分析の絬果平均 $2.6 \%$ の酸素を不純物として含 有することを認めた。

此資驗に使用した試料の銅價平均値は 0.888 であるから，以上 の 2 表より夫々の銅僄增加の値を求めて比較する時は第 3 表の如 くなる。

第 3 表から容易に看取し得るや5に何れの場合でも水で試料を 濡らした埸合の銅價は大きい。詰り水で需らすと光化學變化を促 進サることが分る。次湈筫氣體中の酸素の溇度と銅價增加との 關係を知る第に之を第 1 圖に示す。此圖で明かなやうに水で需ら

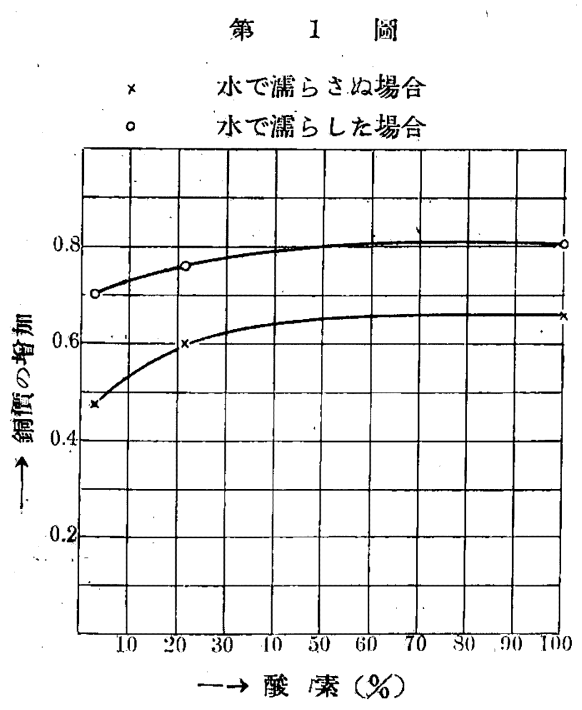

すと酸素濃度 の如何に關ら ず銅價の增加 量は多い。が 然乙酸素濃度 の霄加の影響 は比較的微弱 ぞある。

次に第 3 裴 の銅價唒加量 の差を酸素の 濃度に對して 點経して曲線 を描くと第さ 圆が得られ る。

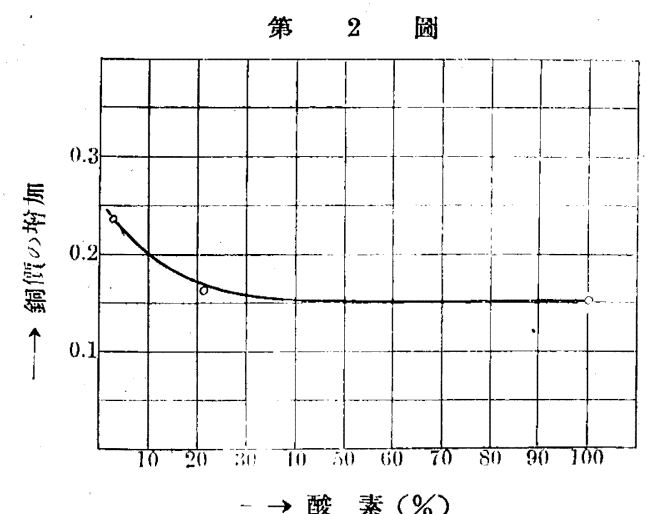

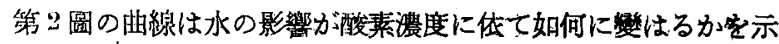
してるるのであつて結局酸素濃度が增寸程見掛けの上からは銅價 に與へる水の影響が弱くなることが分る。立に於て當然起る疑問

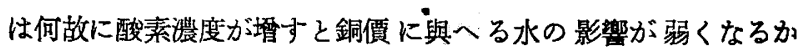
である。別言すれば第 1 圖の上の曲線が下の曲線と何故平行にな らぬかと云ふことである。著者は第 8 報（前出）に於て空素・酸 素の混合系を媒質とする時酸素湌度の小なる間は瀻栍素の光化學 變化は主としてアルデヒド基の生成であり酸素の割合が増すとア ルデヒド基の生成と共に後者の酸化が起り更に酸素が埥すとアル デヒド基の生成と後者との酸化とが略了同速度に於て起るのであ らろと述べた。若しも水の影響がアルデヒド基の生成反應と其酸 化反應に對し同じであるならば第 1 圖の兩曲線は本行にならな ければならない。然るに兩曲線は上記の如く平行でないのである から兩反應に與へる水の影響は等しくないのであつて, 上の曲線 の方が組曲度の少ない點から見て水が存在し而も潤澤なる酸素が 存在するとアルデヒド基の酸化は一層容易になることを示すのの である。

\section{（2）賽 驗 其 2}

上記の實驗の結果に於て繊維素試料を水でよく濡らして氷銀登 の光で照射すると銅價の增加することを明かにしたのであるか ら，次いで試料中の水分含有量と光で照射した後の銅價が如何な

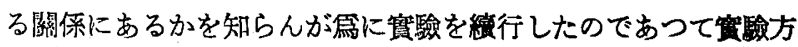
法は總て上に述べた處と同じである。但し何れも空氣中で光を照 射したものである。

贯舲結果 最初に風乾試料（水分含有量 $8.2 \%$ ）に光を照射せ るものの銅價の測定結果を示す。

第 4 表 $8.3 \%$ ○水分を有する試料を光で 照射せるもの」銅價測定結果

\begin{tabular}{|c|c|c|c|c|c|}
\hline 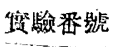 & 倝燥試料 (g) & 銅佯 & |螼驗番號 & 乾燥試料 $(\mathrm{g})$ & 銅揑 \\
\hline 1.94 & $0.6 \pm 62$ & 1.218 & $1: 7$ & 0.6143 & 1.182 \\
\hline 125 & 0.5802 & 1.186 & 128 & 0.6038 & 1.183 \\
\hline 126 & 0.6469 & 1.199 & & 和均 & 1.194 \\
\hline
\end{tabular}

次に $14.1 \% ， 44.2 \%$ 及 $60.0 \%$ の水分を有する試料に就て筫驗 せる結果を示す。 
第 5 表 種々の水分を有する試料に光を照射せるもの」銅價測定結果

\begin{tabular}{|c|c|c|c|c|c|c|c|c|}
\hline \multicolumn{3}{|c|}{ 14.1\% の水分を有する } & \multicolumn{3}{|c|}{ 44.3\% の水分を有するもの } & \multicolumn{3}{|c|}{$60.0 \%$ の水分を有する％の } \\
\hline 缺瞼番㩆 & 㲦燥試料 (g) & 銅 & 虾驗番唬 & 榦燥試料 $(\mathrm{g})$ & 銅 侕 & 留驗番號 & 倝燥試料 (g) & 銅 佂 \\
\hline 148 & 0.6575 & 1.196 & 152 & 0.6558 & 1.218 & 156 & 0.6423 & 1.262 \\
\hline 149 & 0.6446 & 1.188 & 153 & 0.6405 & 1.240 & 157 & 0.6710 & 1.316 \\
\hline 150 & 0.6110 & 1.185 & 154 & 0.5990 & 1.226 & 158 & 0.6176 & 1.273 \\
\hline 151 & 0.6392 & 1.212 & 155 & 0.5971 & 1.217 & 159 & 0.6571 & 1.281 \\
\hline & 45 & 1.195 & & 平 & 1.225 & & $4 \times$ & 1.283 \\
\hline
\end{tabular}

第 4 表及第 5 表より銅價に與ふるる水の影響を求むる時は次の 如くなる。

\begin{tabular}{cccccr} 
& & 第 6 表 & \multicolumn{4}{c}{ 水分の銅價に與ふる影望 } \\
水 & & \\
分(\%) & 8.2 & 14.1 & 44.2 & 60.0 \\
銅 & 便 & 1.194 & 1.195 & 1.225 & 1.283
\end{tabular}

第 6 表を圖に點綴せば第 3 圖が得られる。

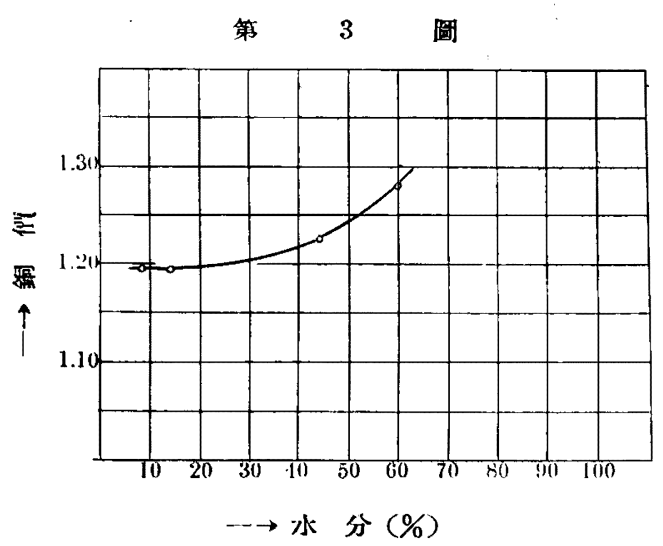

第 3 阳を見るに試料の有する水分が $20 \%$ 以下なる時は瀻維素

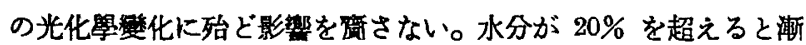
头光化學變化は促進される。緎維素の最大吸缹量は其履歷に依て 星なるから一般的に明確に言へないか，普通大氣中にある䋐維素 の有する水分が $20 \%$ 以上に及ぶと云ふことは崷ろ稀な場合では ないかと思はれるので，繊維素中に吸滋分として含まれてるる水 は光化學變化に影響はないと云つても恐らく云ひ過ぎではあるま い。暴に第 2 報の赛驗に於て試料に濕分を與へても銅價に何等差 を認めなかつたのは多分水分が $20 \%$ を越えなかつた結果だと想 像される。

\section{（3）本驗の終結}

定量用濾紙に就て得られた結果が一般に瀻維素に適用されるも のと假定するならば緎維素中の水分が凡そ $20 \%$ 以下である場合 には水分の多㝝は光化學變化に影譩を與へないが凡そ $20 \%$ 以上 になると光化學攀化は促進される。

試料を充分に善く水で需らして光化學變化を受けしめると上記 の如く其筫化は促進されるが, 銅價より觀察せる酸素の影響は水 で需らさなかつた時に比して微弱である。其原因は恐らく水と酸 素が潤澤に存在すると光化學的生成物なるアルデヒド基が更に光 化學的に酸化される䉆であらら。

\section{第 1 報より第 11 報に至る迄の總括}

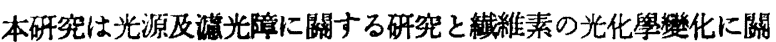

する研究の 2 部分より成る。其中光源の研究は熱電堆・ガルヴ、 メーター法を利用して水銀石英燈，照明用タングステン白熱電球 更ヴ ィイライトランプの發射光線に就て輻射エネルギーの波長 による分布狀態を調べたのである。其結果照明用タングステン白 熱麗球には紫外線存せず, ヴァイタライトランプには凡そ $3600 \AA$ より長波長の紫外線が嚾に存するのみであつて，之等に比すれば 水銀石英燈の紫外線は誠に豐富であへて，本研究には水銀石英燈 を光源とすることの最適なることを知つた。次い、゙濾光障の研究 としては石英ガラス，空ガラス，紫外線透過ガラス，セロファン， ニトロ・フィルム，アセテートフィルム及ベークライト等の薄膜 及薄板の水銀石英燈輻射線の波長別透過來を測定した。其結果石 英ガラス，空ガラス，紫外線透過ガラス（ウルトラヴィト），二ト ロ・フィルム皮アセテート・フィルムは可視光線を略了同程度に透寸 も紫外線の透過度には著しき相違があり，石英ガラスは測定可能 なりし總ての紫外線を透すす空ガラスは $3620 \AA$ より短波長の輻 射線に對しては全く不透資であり，紫外線透過ガラス，二トロ・ フィルム,アセテートフィルムは $2640 \AA$ 及其より短波長の輻射線 を完全に阻止することを知つた。更にセロフっンは可視部紫外部

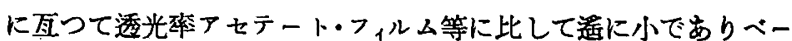
クライトは紫外線に對して全く不唀貿であるのみならず可視光線 の透光率も上記物筫に比して遥に小なることを明かならしめた。 囚に此測定は纎維素の光化學變化が凡そ如何なる範总の波長を有 する輻射線に依て起るかを知らんが爲の準備的研究である。

繊維素の光化學的研究としては初め數種の械維素試料を取り预 備的赛驗を行ひたる處均一に光の作用を受け得る滤紙を試料とす ることの最も宜しきことを知り之を試料として研究を進めた。先 つ試料を水銀石英嬁の光で照射した後銅価を测定したるに銅價の 增加することを確め得た。これ織維素は光の作用に依て其分子內 に還元基の生成することを示すものである。假に之を還元性纎維 素々名づけて置く。この還元性繊維素の光化學的生成は空素, 水 素、炭酸ガス等を媒質とする場合にも起り必ずしも酸素の存在を 必要とせざることを明かならしめた。尤す空素・酸素 2 成分混合 系を媒質とする場合には酸素濃度が凡そ $20 \%$ (签積)に至る迄 は酸素が多い程還元性繊維素の生成を促進するが其以上の酸素淟 度の增加は還元性繊維素の增加に殆ど關係はない。之は恐らく酸 素の增加は還元性繊維素の生成の外に後者の還元基の酸化を譑起 せしめる䉆であらら。また還元性㵶維素の光化學的生成は媒質氣 體の特殊性に支配され水素及炭酸ガスは空素よりも遙に其生成を 容易ならしめる。次に水分の影響は凡そ $20 \%$ (試料に對する水 分）上下では光化學變化に無關係であるが試料中の水分が $20 \%$ を超ゆる時は此變化を促進する。次に微量の菏性ンーダの存在は 光化學變化に影響を畄さない。

湧光障を使用して特定の波長の輻射線を阻止して兾驗を行ひ輻 射線の波長と光化㦛變化の關係を調へたるる處，輻射線は短波長ほ 


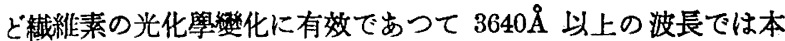
賓臨者の探用條件の下では殆ど光化學變化の迅らぬことを明かな らしめた。
附記 本研究は日本學獄振興會の御嗳助を得て施行せるもので ある。因て姣に記るして深厚なる謝意を表する。

（南淽洲践道株式會社）（昭和 12 年 10 月 29 日受理）

\title{
（3）木 材 の 糖 化 及 醇 酵（第 2 報）
}

\section{稀硫酸に依る各種木材の糖化及び糖化液の醇酵}

\author{
鎌 塚 明 - 山川 昇・六所 文三
}

第 1 報（本誌，昭和 $12 ， 40,259)$ に於て漰洲產針葉樹材の鋸 耑を試料とし、オートクレーヴを用ひ，稀硫酸による逐次數包の 糖化を行々場合の糖化條件と糖收量との關係を見た。本報に於て 此關係を照し滿洲産の針葉樹, 潤葉樹各數種琬につき糖化を行 ひ，得た糖收量及その酒精酿酵成績を報告する。

試料

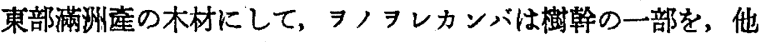
は綕て樹皮を除いた丸太材を當所に於て鋸㡈となし試料とした。 樹種及樹齡を年輸より算した結果を示せば次の如くである。

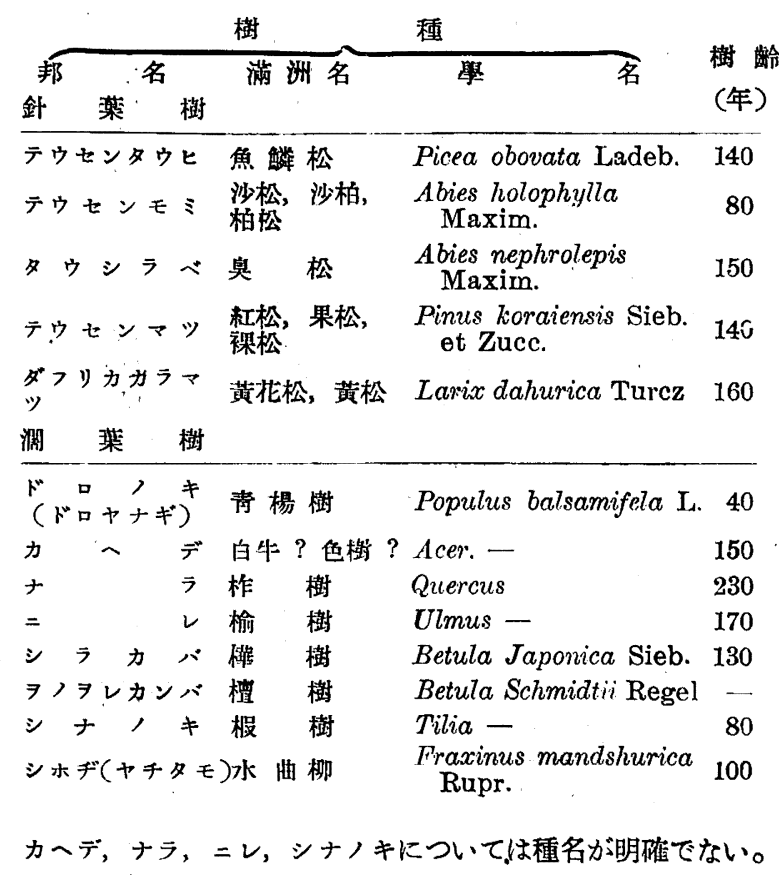

$$
\text { 分 析 }
$$

分析方法は第 1 報に記載した方法を用ひた。分析結果は第 1 表 に示す如くである。

第 1 表の分析結果より見れば、一般に猃葉樹に於ては濶葉樹 に於けるよりも酸酵糖收量は大である。

\section{驗 方 法}

試料約 $55 \mathrm{~g}$ をとり，所定條件に於て糖化を行つた後，生成糖液

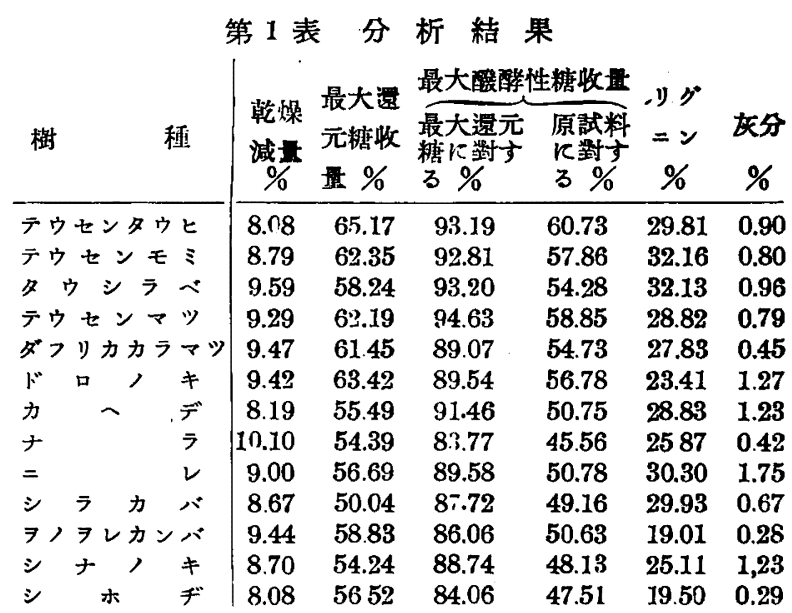

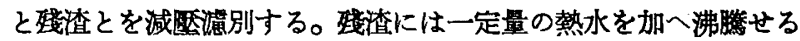
水浴中で 10 分間糖の洗淮抽出を行ふ。洗㴚抽出液を最初の糖溶 液に加へ一部をとり, 糖濃度, 糖收量を求め, 他の部は $\mathrm{CaCO}_{3}$ で中和し， $\mathrm{CaSO}_{4}$ を濾別し， $\mathrm{KH}_{2} \mathrm{PO}_{4} 0.2 \mathrm{~g}, \mathrm{MgSO}_{4} \cdot 7 \mathrm{H}_{2} \mathrm{O} 0.1 \mathrm{~g}$ ， $\left(\mathrm{NH}_{4}\right)_{2} \mathrm{SO}, 0.2 \mathrm{~g}$ を糖溶液 $100 \mathrm{cc}$ につき加入, 常法により殺菌 し Rasse II を用ひ酒精酸酵試驗を行つた。洗源抽出を行つた殘 渣は常溫に於て 1 週間乾燥し，次の糖化に使用した。

第 1 次糖化は溫度 $160^{\circ} \mathrm{C}$, 硫酸濃度 $0.5 \%$, 時間 15 分, 第 2 次以後各次糖化は何れも溫度 $170^{\circ} \mathrm{C}$, 硫酸漕度 $2.0 \%$, 時間 30 分 の條件に於て行つた。酸量は第 1 次糖化は乾燥試料の 7 倍, 第 2 次糖化 $200 \mathrm{cc}$, 第 3 次糖化 $120 \mathrm{cc}$, 第 4 次糖化 $70 \mathrm{cc}$ を用ひた。

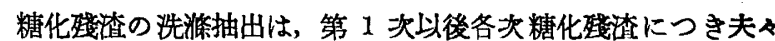
$80 \mathrm{cc}, 60 \mathrm{cc}, 40 \mathrm{cc}, 40 \mathrm{cc}$ を用ひた。

\section{糖化及䁖酵}

糖化及酚酵結果は第 2 表に示す如くである。 第 2 表に於ける蜜驗值は總て乾㫧試料に對して計算せる值であ る。各試料に就て 4 次の糖化を終へた残楂は充分洗源し $80^{\circ} \mathrm{C} に$ 於て 6 時間乾燥した。一般に酸量を小にすれば糖溶液の濃度は 增加するす 4 次糖化の糖收量は娍少する。本試驗に於ては糖化䂝 滥の洗源抽出は I包に止めたが，更に第２问洗淡抽出を行へば 佾少量の糖の得られることは著者等の經驗せる所である。此少量 の糖は本試驗に於ては次包糖化に於て, 糖化の最初より分解作用 を受くへく，惯際の糖收量は第 2 表に示した值より多少大と考 へられる。また第 2 尼洗涤抽出液を合寸れば糖浱度の娍少を來才 